\title{
Rodzina ludzka w aspekcie paradygmatu Edenu. Analiza skrypturystyczno-patrystyczna
}

\author{
ks. Marian Bendza \\ Katedra Historii Kościoła Powszechnego i Autokefalicznych Kościołów Prawosławnych \\ Chrześcijańska Akademia Teologiczna w Warszawie \\ Polska \\ mbendza@interia.pl
}

Fr. Marian Bendza, The Human Family in the Aspect of the Eden Paradigm. A Scriptural and Patristic Analysis, Elpis, 18 2016: 51-56.

\begin{abstract}
The Eden paradigm and the human family are presented here not in opposition, but in their complementary character. The paradigm of Eden permits us to better illustrate the problem of family life and family community reveals human dignity and one's potential to believe. The author of this article did not use any form of proselytism, but in contrast, only would like to present existential, biblical and patristic truths.
\end{abstract}

The paradigm of Eden, according to the author, consists of three elements: a relationship with God, equal dignity for men and women and openess to religion (theosis). Thanks to these elements, we can also understand the dignity of the family, which is not only a "cell" of society, but above all of the Church.

\begin{abstract}
Streszczenie: Paradygmat Edenu i rodzinę ludzką przedstawiono tu nie przeciwstawnie, lecz w ich komplementarności. W świetle Edenu życie rodzinne, wspólnota rodzinna najpełniej odsłania godność człowieka i jego możliwości wiary. Autor tego artykułu omija wszelako jakąkolwiek formę prozelityzmu, wprost przeciwnie, pragnie jedynie przedstawić prawdę zarówno egzystencjalną, jak biblijną czy patrystyczną.
\end{abstract}

Paradygmat Edenu, według Autora, składa się z trzech elementów: przyjaźni z Bogiem, jednakowej godności ludzkiej (takiej samej u kobiety, jak u mężczyzny) oraz otwartości religijnej (przebóstwienie). Dzięki tym trzem elementom odsłania się też godność rodziny, nie tylko podstawowej „komórki” społeczeństwa, lecz przede wszystkim Cerkwi.

Keywords: The Book of Genesis, the patristic mind, human being, creation, family

Słowa kluczowe: Księga Rodzaju, myśl patrystyczna, człowiek, stworzenie, rodzina

\section{Prawo naturalne istotnym faktorem zaistnienia Edenu}

Tak sformułowany śródtytuł może wywołać niejaką konsternację: jeżeli w tradycyjny sposób pojmujemy legem naturalem jako zbiór norm obowiązujących każdego człowieka, czy to sprawującego władzę, czy też jej podległego, dostrzegamy w nim bezdyskusyjny wzorzec każdej formy ustawodawczej czy prawodawczej, której naturalną kontekstualizacją będzie ocena konkretnego postępowania danej społeczności lub danej jednostki.

Zasadniczą grupą społeczną, stanowiącą przedmiot analizy prawno naturalnej jest rodzina, gdyż wydaje się ona być najbardziej „wzorcową” wypadkową naturalnych odniesień zarówno interpersonalnych, jak i wynikłych z funkcjonowania w danym otoczeniu. Rodzina w tym kontekście wydaje się rzeczywistością aksjomatyczną, nie domagającą się definicyjnego opracowania: kobieta + mężczyzna + dziecko bądź dzieci, aczkolwiek pojawiają się głosy, iż myśl współczesna powinna wypracować definicję tej rzeczywistości aksjomatycznej, co z natury rzeczy nie wydaje się możliwe.
Wyrazem takiego podejścia do zagadnienia jest zastąpienie postawy pogodzonej z aksjomatycznością zagadnienia dość meandrycznie poprowadzoną refleksją, zarzucająca , tradycyjnemu, kościelnemu” ujęciu wstecznictwo i brak nowoczesności. Stworzono w ten sposób dość „skomplikowane" odniesienia:

Mężczyzna + mężczyzna + (adoptowane) dziecko

Kobieta + kobieta + (adoptowane) dziecko.

Nie trzeba dodawać, iż tak przeprowadzonym analizom nie pozwolono skonfrontować się z prawem naturalnym, generując nową jakość matrimonii jako societatis amicalis, wspólnoty partnersko-przyjacielskiej, gdzie obie „jednakowo płciowe” strony mają być autentycznym punktem odniesienia zarówno dla adoptowanych dzieci, jak i dla nich samych, dysponujących wszelako zróżnicowanymi uprawnieniami: jedna macierzyńskimi, druga ojcowskimi. Nie trzeba dodawać, iż w konsekwencji zmienia się ogląd płci (zastąpionej dość enigmatycznym gender ${ }^{1}$ ), czy na rodzinę jako taką: odmówiono jej zasadniczego celu, prokre-

\footnotetext{
Które to słowo w języku angielskim i tak oznacza płeć albo rodzaj.
} 
acyjności, sprowadzając rzecz do hedonizmu, samozaspokojenia, czyli do różnorodnych form egoistycznych

Refleksja teologiczna nie powinna w tym przypadku milczeć, acz nie powinna też wchodzić na zbędne drogi prozelityzmu czy włączać się do „taniej” propagandy politycznej, jak to również w ostatnich latach odnotowujemy w Polsce. W naszym przypadku optymalnym wyjściem z sytuacji będzie analiza obrazu edeńskiego jako konkretyzacji prawa naturalnego, prawa Adonai (יאנודא)'

Wybór taki nie jest przypadkowy. Obraz Edenu charakteryzuje się, jak większość obrazów biblijnych, symbolicznością i jasno zarysowanymi odniesieniami dydaktycznymi, ma więc znaczenie parenetyczne $e^{3}$ paradygmatyczne ${ }^{4}$ zarazem - może więc być uznany za wzorzec zarówno światopoglądowy, jak i antropologiczny.

Autor biblijny umieszczając go na początku rozpoczynającego Księgę Genesis dydaktycznego poematu stworzenia, wydaje się niejako sugerować ponowną inicjację historii świata i człowieka. Ujęcie antropologiczne zdaje się tu dominujące: nawet Bóg przedstawiany jest jako Osoba ludzka, widzialna, Która zakłada dla ludzi Eden, rajski ogród ${ }^{5}$, przebywa między ludźmi na ziemi, pozostaje z nimi w przyjaźni... Jednocześnie pozostaje Kimś, co stwarza ex nihilo, a to jedynie Pan potrafi uczynić, czuje się uprawniony do deklaracji stworzenia człowieka na Obraz Swój i podobieństwo ${ }^{6}$, by zapewnić ludziom niezbywalną godność, niezależną od uwarunkowań otoczenia czy własnych, osobistych losów. Stworzył więc Bóg człowieka na swój obraz, na obraz Boży go stworzył: stworzył mężczyznę i niewiastę ${ }^{7}$.

Najważniejszym dla naszych dalszych rozważań elementem przedstawionego przekazu wydają się słowa: stworzył ich jako mężczyznę (isz-היאיאו i kobietę (iszáNiewątpliwie, w przekazie tym wyróżnić można dwa elementy jako istotne: podobieństwa określeń odnoszących się do płciowości człowieka (isz, iszá) i zastosowany przyimek we, „i”.

\footnotetext{
Wyżej określenie hebrajskie znaczy tyle co „Pan” (gr. Kupıৎ). Używa się go w hebrajskim tekście Pisma Świętego Starego Testamentu. Może występować niezależnie, albo zamiast świętego tetragramu JHWH (składającego się z czterech spółgłosek JHWH - הוהי, który jest niewypowiedzialnym imieniem Boga). Żydzi odczytują wyżej wymieniony tetragram jako Adonai (Pan). W przekładzie greckim starego testamentu zwanego septuagintą, tetragram JHWH został przetłumaczony jako Kyrios (Pan). Dokładnej wymowy JHWH nie znamy (szerzej patrz: Encyklopedia Chrześcijaństwa. Historia i współczesność. 2000 lat nadziei, wyd. JEDNOŚĆ, Kielce 2000, s. 305.

3 Od gr. $\pi \alpha \rho \alpha \delta \varepsilon \imath \gamma \mu \alpha$ - przykład, wzór.

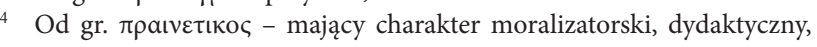
pouczający.

$R d z$ 1,8; hebrajskie gan-eden (ogród) ודא נג za pomocą, którego w Księdze Rodzaju określone jest Eden - „Raj na ziemi”, septuaginta oddaje słowem paradeisos ( $\pi \alpha \rho \alpha \delta \varepsilon เ \sigma o \varsigma)$, stanowiącym kalkę hebrajskiego synonimu מדרפ pardes (Pnp 4,13; Ne 2,8; Koh 2,5) wyraża ono przyjaźń z Bogiem i stworzeniami, którą się cieszył człowiek przed swoim grzechem - upadkiem. Nowy Testament obok pojęcia „raj” (Łk 23,46; 2 Kor 12,4; Ap 2,7) sięga po różne i inne obrazy, takie jak niebo, ziemia obiecana, świątynia, nowa Jerozolima, czy uczta niebiańska na oznaczenie stanu ludzi sprawiedliwych po śmierci. Kościół rozumie pod nim, zbawienie polegające na doskonałym połączeniu się z Bogiem.

6 Por. $R d z 1,26$;

$7 R d z 1,27$
}

Pierwszą trudność rozwiązuje sam autor biblijny: albowiem z męża została wzięta $(R d z 1,23)^{8}$, co w biegu nie tylko judaistycznej historii chętnie interpretowano jako podległość kobiety mężczyźnie?.

Taką jednak możliwość interpretacyjną redukuje wspomniany przyimek: nawet autorowi starożytnemu znane już było podstawowe prawo logicznej koniunkcji, sugerującej jednakowy sposób uczestnictwa, jednakowy stopień zaangażowania w człowieczeństwo, jednakowe przywileje i powinności, więc nie mógł, zarysowując jednoznaczne zróżnicowanie płciowości zróżnicować również człowieczą godność. A więc w kontekście paradygmatu Edenu dostrzegamy równość $\mathrm{w}$ godności, równość w możliwościach przebóstwienia.

Bezpośrednia analiza biblijnego obrazu stworzenia człowieka (zwłaszcza passus $R d z$ 1, 26-28) wskazuje jeszcze na dwie egzystencjalne wartości, wynikające z omawianego zagadnienia: posiadanie zdolności poznawczych ${ }^{10} \mathrm{i}$ uzdolnienie do miłości. Te dwie kategorie nabierają szczególnego znaczenia w kontekście rodzinnym, pozwalając, by istniała ona jako grupa osób, jako część społeczeństwa, nie zaś anonimowa, stadna zbiorowość.

\section{Obraz i podobieństwo Boże fundamentem godności}

Rozpatrując bardziej szczegółowo zarysowane wyżej propedeutycznie zagadnienia, warto zauważyć, iż jednoznaczne różnicowanie prezentacji obrazu i podobieństwa, czyli jakoby „noszenie” przez osobę ludzką obrazu Bożego i upodobnianie się do Niego w rozumności myśli i czynów, potwierdza autonomiczność obu tych niezależnych od siebie rzeczywistości. Jak się jednak na podstawie późniejszej refleksji przekonamy, obie przedstawione kategorie nie są od siebie tak odległe, co więcej, wykazują swoistą ich komplementarność.

Warto jednak uczynić zastrzeżenie, iż Stwarzający generując obraz czy podobieństwo nie mógł pominąć nieprzekraczalnej granicy między tym, co Boże, a tym, co ludzkie. Jakość tego „odwzorowania Siebie” zamknął w kategoriach dostępnych ludzkości. Tak więc stworzony nie jest innym Bogiem, lecz jest człowiekiem i jako taki ma udział we wszystkich prerogatywach istnienia wyznaczonych mu przez Boga. Antropologiczny wymiar istnienia pełni w tym przypadku rolę decydującą powodując, iż kategoria zarówno obrazu, jak i podobieństwa zmieści się w obszarze semantyki humanistycznej, nie zamykając się wyłącznie do

\footnotetext{
8 Jest to deklaracja mężczyzny: Ta dopiero jest kością z moich kości i ciałem z mego ciała! Ta będzie się zwała niewiastą (iszá), bo ta z mężczyzny (isz) została wzięta.

9 Podobne nastawienie spotykamy zresztą także w teologii pawłowej. Oto kilka przykładów: Mężczyzna jest głową kobiety (1 Kor 11,3); To nie mężczyzna powstał z kobiety, lecz kobieta z mężczyzny (1 Kor 11,8) i wiele innych, odnośnie do posłuszeństwa, form modlitwy, a nawet... grzeszności. 10 Te niezwykłe zdolności poznawcze przejawiają się zwłaszcza w procesach wyobraźni, sylogistycznym myśleniu czy umiejętności przewidywania. Ważną sprawa jest też możliwość samooceny.
} 
teologalnej. Inaczej mówiąc: pleroma $(\pi \lambda \eta \rho \omega \mu \alpha)$ istnienia uzależniona jest od kondycji ludzkiej, nie zaś Bożej.

I rzekł Bóg: „Uczyńmy człowieka na obraz i na podobieństwo nasze; a niech panuje nad rybami morskimi i nad ptactwem powietrznym, i nad zwierzętami, i nad wszystką ziemią, i nad wszelkim płazem, który pełza po ziemi. I stworzył Bóg człowieka na obraz swój, na obraz Boży stworzył go, mężczyzną i niewiastą stworzył ich" ( $R d z 1$, 26-27).

Deklaracja kreatywności, jak moglibyśmy nazwać przytoczony fragment, bardzo szczegółowo ukierunkowuje naszą refleksję, wyszczególniając kontekst panowania nad wszystkimi bytami stworzonymi. Człowiek jako pan stworzenia uczestniczy w niezwykłym misterium Boga, w Którym i dzięki Któremu znajduje swą wyjątkowość.

Zakres tego uczestnictwa obejmuje człowieka jako gatunek, zarówno kobietę, jak i mężczyznę ${ }^{11}$. Uczestnictwo we wskazanym misterium pozwala też każdemu człowiekowi egzystować jednocześnie jako proch ziemi, czyli część natury i jako odwzorowanie Boga w zrodzeniu ku nadprzyrodzoności.

Obraz Boży w człowieku nie pozwala też na „bezkarne przelanie krwi ludzkiej” (por. $R d z$ 9,6). Zostanie on wzmocniony Bożym apelem z góry Synaj: Nie będziesz zabijał!

Zagadnienie obrazu i podobieństwa Bożego to jeden z naczelnych tematów antropologii chrześcijańskiej. Słowo

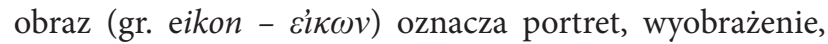
cielesno-duchowe stworzenie według wzoru i posiadanie do tego wzorca upodobnienia. Można więc powiedzieć, iż w pojęciu „obraz” zawiera się też immanentnie „podobieństwo", lub bardziej precyzyjnie, iż obraz i podobieństwo wzajem się uzupełniając, prezentują rzeczywistość istnienia ludzkiego.

Analiza patrystyczna w tej mierze nie jest jednak spójna $^{12}$ i charakteryzuje się dość arbitralnym podejściem do zagadnienia, co uzależnione jest zapewne oddziaływaniem środowisk przez poszczególnych Ojców Kościoła reprezentowanych.

Wywodzący się z Aleksandrii św. Klemens (150-212) podobieństwo do Boga uważa za rzeczywistość dynamiczną, która jest rodzajem stymulacji do podjęcia procesu całkowitego upodobnienia się do Boga. Można zatem uznać, iż Eden był tylko inicjalnym etapem rozwoju, którego celem było osiągnięcie pełni stworzenia w apogeum boskiego upodobnienia.

Wskazany autor w Słowie zachęty dla pogan miano obrazu odnosi do umysłu człowieka, w innym zaś swym dziele, Wychowawca, ogranicza semantykę tego pojęcia do zdolności rozrodczych ${ }^{13}$. W każdym jednak przypadku trwa bar-

\footnotetext{
11 Por. ks. M. Kaszowski, Żywy obraz i podobieństwo Boga, WWW. teologia (dostęp 10.XII.2014).

12 Podobne zjawisko zaobserwujemy w znanej powszechnie przypowieści o synu marnotrawnym, zwanej także przypowieścią o miłosiernym Ojcu.

13 Święty Klemens dość dosadnie odnosi się do antropogenezy w słowie wstępnym swoich Kobierców: „różni ladaco i nicponie powiadają, że człowiek został utworzony ze sprzecznych sił, a mianowicie: aż do pępka jest dziełem boskiej ręki, lecz poniżej - dziełem kogoś gorszego; stąd istnieje $\mathrm{w}$ nas pragnienie obcowania seksualnego. Wszelako uszło ich uwagi, że i wyższe partie ciała zdradzają pragnienia, na przykład pokarmu i nawet
}

dzo mocno na stanowisku, iż byt ludzki pochodzi od Boga, który stworzył nas integralnie, od wewnątrz i od zewnątrz ${ }^{14}$.

Istotnym faktorem stworzenia jest działanie Logosu, przejawiające się choćby $\mathrm{w}$ skuteczności oddziaływania zamysłu Bożego stworzenia $\mathrm{z}$ zainicjowaniem ludzkiej egzystencji ziemskiej. Logos miał niejako „wskazać” człowiekowi jego szczególne miejsce na ziemi, co się zdarzyło, gdy Bóg własnymi rękoma go czynił, o innych zaś rzeczach mówil, by się stawały ${ }^{15}$.

Poglądy św. Grzegorza z Nyssy (335-395) również charakteryzuje niejednoznaczność recepcyjna omawianego zagadnienia. W rozprawie Dziewictwo czytamy, iż określenie „na obraz” odnosi się do wzbogacenia człowieczeństwa pochodzącym od Boga intelektem i wolną wolą. $\mathrm{Z}$ kolei w dziele Stworzenie człowieka ejkon utożsamiany jest z bogactwem cielesnych i duchowych darów, którymi od początku swego istnienia może radować się człowiek.

Bardzo interesującym stwierdzeniem tego autora jest uwaga, iż cechy, które posiada jednostka ludzka (inteligencja, mądrość, zdolność mówienia, miłość), zostały stworzone na obraz takich samych odpowiednich kategorii istniejących w Bogu, przeto obraz i podobieństwo Boże mogą egzystować w człowieku. Fundamentalną i najważniejszą z nich jest Niestworzoność Boga, usytuowana w opozycji do człowieka, istniejącego wszak w nim dzięki aktowi stworzenia ${ }^{16}$.

Dlatego też zdaniem św. Grzegorza prawdziwa wielkość antropologiczna jest wynikiem wspólnoty (społeczności) z Bożą pełnią, to jest ukrytej w nim tajemnicy obrazu i podobieństwa. Obraz ten zostaje zaszczepiony w ludzkiej duszy, by budził tęsknotę za pierwowzorem, ewokując realizację odwiecznego dążenia tak poszczególnych jednostek, jak i ludzkości do uczestnictwa w dobrach wiecznych. Zdolność ta ma zwłaszcza wymiar soteriologiczny, prowadzi bowiem do osiągnięcia duchowej jedności utraconej przez grzech.

Taki punkt widzenia opiera się na antropologicznym poznawaniu jako istotnej kategorii egzystencji ludzkiej, kategorii dość szczegółowo opisanej przez Apostoła Narodów: „Wy zaś nie tak poznaliście Chrystusa, o ile jednak słyszeliście o nim i w nim zostaliście pouczeni, jaka prawda jest w Jezusie, abyście złożyli starego człowieka co do dawnego sposobu życia, który się psuje przez zwodnicze żądze. Lecz odnówcie się duchem umysłu waszego i obleczcie w nowego człowieka, który stworzony jest według Boga w sprawiedliwości i świętości prawdy" (Ef 4, 20-24) ${ }^{17}$.

Epifaniusz, biskup ${ }^{18}$ cypryjskiej Salaminy (315-403)

w pewnych wypadkach okazują niepowściagliwość. Ci ludzie przeciwstawiają się samemu Jezusowi Chrystusowi, który powiedział do faryzeuszy, że Bóg stworzył nas jako ludzi zarówno wewnątrz, jak i z zewnątrz". Cytuję za ks. S. Łucarz, Grób czy świątynia, Kraków 2007, s. 21.

14 Por. powyższy cytat.

15 Ks. S. Łucarz, dz. cyt., s 32

16 Św. Grzegorz z Nyssy, O naśladowaniu Boga, Kraków 2001, s. 19-20.

17 Tamże

18 Na urząd biskupa wstąpił jako mnich działający w Palestynie. Przybywszy do cypryjskiej Salaminy nie porzucił ani stroju, ani obyczajów zakonnych, budując wiernych nie tylko wielką obyczajnością, lecz i wiedzą, przewyższającą ówczesny poziom przygotowania naukowego. Por. Euzebiusz z Cypru, Wikipedia [strona polska] (dostęp 15 grudnia 2014). 
wywodzący się z rodziny żydowskiej i dopiero w późniejszym okresie życia nawrócony na chrześcijaństwo wielki erudyta, znawca wielu języków ( $w$ tym syryjskiego, greckiego i łacińskiego), z uwagi na swe pochodzenie dogłębnie rozumiał omawiane zagadnienie: „Nie ma wcale potrzeby określać czy stwierdzać stanowczo, w której części (ciała ludzkiego) urzeczywistnia się to, co jest 'na obraz' Boży; należy po prostu uznać, że ten obraz jest w człowieku, abyśmy nie odrzucili łaski Boga i nie stracili wiary w Niego. Ponieważ wszystko, cokolwiek Bóg mówi jest prawdą, więc jest prawdą także i to, co nawet pod pewnym względem wymknęło się naszemu rozumieniu" ${ }^{\prime \prime}$.

Ŝw. Atanazy Wielki (ok. 295-373) swe poglądy na naturę stworzenia człowieka wiąże $\mathrm{z}$ zaangażowaniem w spory trynitarne, szczególnie mocno dające znać o sobie w kontekście Soboru Nicejskiego z roku 325. W związku z tym wskazany autor zwraca szczególna uwagę na ontologiczny charakter uczestnictwa człowieka w tym co Boże, czyli w Trójcy Świętej, obraz Której w owym czasie się krystalizował, a Której on sam był wielkim obrońcą. Trójca może być uznana za odwzorowanie rodziny, gdzie obraz człowieka przejawia się najbardziej dynamicznie ${ }^{20}$. Podobieństwo zaś do obrazu Bożego dostrzega omawiany Autor w oświeconym umyśle ${ }^{21}$.

Podobne stanowisko reprezentował św. Bazyli Wielki (329-379): „niby w mikrokosmosie dostrzeżesz w sobie odbicie Bożej Mądrości”22. Ten święty Ojciec z Kapadocji odwołując się do Bożej imperatywności podkreśla: „Człowiek jest stworzeniem, które otrzymało rozkaz stania się Bogiem". Rozkaz ten ma jednak na względzie ludzką wolność, nie jest przeto przymusem.

Jego zaś przyjaciel ze szkolnej ławy, św. Grzegorz z Nazjanzu (330-390), zwraca uwagę na inny aspekt rzeczywistości obrazu: „Człowiek jest nie tylko podporządkowany prawu moralnemu, nie tylko podlega nakazom boskim, lecz jest „z Jego rodu”, krewnym Boga /.../ Fakt bycia Jego obrazem czyni go zdolnym do przenikania w głąb życia Bożego (theosis)”23. „Bóg - kontynuuje wskazany Ojciec kapadocki - obdarzył człowieka nadając mu wolność, aby dobro należało do tego, kto je wybrał, nie mniej niż do tego, który ustanowił początki dobra w naturze"24.

Zdaniem Orygenesa (184-254) „człowiek został zaszczycony obrazem, gdy został stworzony, ale pełna doskonałość Bożego podobieństwa zostanie mu nadana po wypełnieniu wszystkich rzeczy".

Omawiane zagadnienie stanowiło przedmiot refleksji także chronologicznie późniejszych myślicieli i mistyków prawosławnych. Odwołajmy się do św. Grzegorza Palamasa (1296-1259), dla którego obrazem Bożym w człowieku

\footnotetext{
19 G. I. Mantzaridis, Przebóstwienie człowieka, przekład Iga Czaczkowska, Lublin 1997, s. 23.

20 Co kosztowało go aż pięciokrotne wygnanie $\mathrm{w}$ różne strony $\mathrm{z}$ aleksandryjskiej biskupiej stolicy.

21 P. Evdokimov, Kobieta $i$ zbawienie świata, przekład z francuskiego Elżbieta Wolicka, Poznań 1991, s.68.

22 Cytat tamże, s. 69.

23 Por. tamże

24 W. Łosski, Teologia mistyczna Kościoła Wschodniego, przekł. Maria Sczaniecka, Warszawa 1989, s. 76 - 77.
}

jest nie tylko dusza, lecz także i ciało. I ten święty teolog odwołuje się do relacji, postrzeganej jednak jako contrapositionem cielesności w odniesieniu do rzeczywistości duchowych. Przeciwstawienie to stanowi fundament dynamicznego powiązania całego człowieczeństwa, aczkolwiek przy zachowaniu autonomiczności obu „perspektyw istnienia", czyli bez zmieszania elementów cielesnych i duchowych.

Wydaje się, iż hezychasta wskrzesza niemal o tysiąclecie oddaloną myśl św. Ireneusza (140-202), który nauczał, że określenie obraz odnosi się zarówno do duszy jak i ciała człowieka ${ }^{25}$ : „Człowiek jako dzieło ukończone, jest całością stanowiącą jedność złożoną z duszy, która przyjmuje Ducha od Ojca i która stanowi jedno z ciałem, ukształtowanym na obraz Boga"26.

\section{Człowiek w wymiarze edeńskiej wspólnoty rodzinnej}

Rzeczywistość Edenu zwraca uwagę na jeszcze jedną, ważką kategorię rajskiego rodzinnego bytowania: przyjaźń z Bogiem. Przyjaźń ta wyraża się zaś kilkustopniowo:

- Bóg przechadza się po posadzonym przez Siebie rajskim ogrodzie

- ludzie nie odczuwają wstydu, mimo iż są nadzy;

- czystość moralna gwarantuje im nienaruszalność takiego stanu rzeczy.

Dynamika biblijnego przekazu sugeruje jednak, iż tak idealny, by nie rzec idylliczny obraz relacji między Bogiem a człowiekiem został zakłócony szatańską ingerencją. Mimo zmiany kondycji egzystencjalnej, wywołanej grzechem (wygnanie z Raju), mimo doświadczenia śmiertelności czy chorób, sama istota człowieczeństwa nie uległa jednak zmianie. Nadal jej fundamentem pozostała godność i otwartość na Boga.

\section{a) Godność osoby ludzkiej}

Godność mężczyzny jest godnością człowieka.

Godność kobiety jest godnością człowieka.

Godność ta w pewnej mierze podobna godności anielskiej $^{27}$ stanowi doskonałe uzupełnienie wskazanej wyżej Bożej przyjaźni. W akcie tym, podobnie jak w akcie stworzenia, dostrzec możemy szczególną „opiekuńczość” Bożą, która nie pozwala na żadne odniesienia negatywne w relacjach interpersonalnych, nie pozwalając zwłaszcza na pogardę, gdyż byłaby to pogarda okazana samemu Stwórcy.

Człowiek widziany oczyma autora biblijnego to byt nie tylko przez Boga stworzony, lecz i przez Boga umiłowany. Taki punkt widzenia można zamknąć w ramy dwu łacińskich sentencji chrześsijańskich: Deus Caritas est et vita omnium in amore existat - Bóg jest Miłością, a życie wszystkich trwa w Miłości. Innymi słowy, parafrazując ateńskiego poetę: w Bogu poruszamy się i jesteśmy (por. $D z$ 17,28). Zacytowane słowa sugerują trzy podstawowe funk-

\footnotetext{
25 Za G. I. Mantzaridis, dz. cyt., s. 26.

26 Por. O. Clement, Ciało śmiertelne i chwalebne, Warszawa 1999, s. 9.

27 Por. Ps 8,7. Słowo „anioł” pojawia się w przekładach - tekst oryginalny mówi raczej o „istotach niebiańskich”.
} 
cje egzystencji ludzkiej (życie, działania i trwanie), ukazując pierwiastek Boży nie tylko jako zakorzeniony w człowieczeństwie, lecz wyrażający się również współdziałaniem człowieka ze Stwórcą.

Teologiczna wizja godności człowieka zdaje się pomijać incydentalne aspekty jego bytowania. Nie mówimy wszak o większej godności ludzkiej w odniesieniu do przedstawiciela razy żółtej czy o poszerzonej gamie prerogatyw w przypadku Aryjczyka.

Antropologia skrypturystyczna godność człowieka rozpatruje niejako dwuwymiarowo: w komparacji z egzystencją Bożą i w sposób „absolutny”.

W pierwszym przypadku egzystencja Boża nie jest tylko punktem odniesienia, lecz zdecydowaną dominantą, która każe postrzegać człowieka jako nicość i marność. Wtedy „poziom godności” warunkuje sam Bóg, co dostrzegamy choćby w odniesieniu do rodzinnego dramatu pierwszej bratobójczej walki między Kainem i Ablem: po zabójstwie umotywowanym zazdrością nie pozostawiono Kaina samego sobie, lecz Bóg obdarzył go znamieniem, dając poznać, iż szczególną otacza opieką i chroni przed ewentualnymi atakami. Był to już jednak inny rozdział dziejów rodziny ludzkiej, wygnanej jednak już z Edenu, aczkolwiek nie wyrzuconej „poza nawias” Bożej Miłości ${ }^{28}$. W tym kontekście możemy doświadczyć swoistego egalitaryzmu: godność wielkiego grzesznika jest taka sama jak godność człowieka niemal bezgrzesznego.

W drugim przypadku godność ta jawi się jako coś niezmiernie istotnego i w pewnej mierze niezwykłego, gdyż człowiek to istota żyjąca w Bogu, nawet w pewnym sensie boska.

Syrach, Mędrzec Pański dostrzega jednak, iż ta wielka godność wyszła z prochu: „Pan stworzył człowieka z ziemi i znów go jej zwróci. Odliczył ludziom dni i wyznaczył czas odpowiedni oraz dał im władzę nad wszystkim, co jest na niej. Przyodział ich w moc podobną do swojej /.../ Dał im wolną wolę, język i oczy, uszy i serce zdolne do myślenia. Napełnił ich wiedzą i rozumem, o złu i dobru ich pouczył”29...

A Księga Mądrości uzupełnia: „Żaden z królów nie miał innego początku narodzin: jedno dla wszystkich wejście w życie i wyjście to samo" $(M d r 7,6)$.

Nie możemy tracić z pola widzenia oddziaływania Bożego w Miłości, która swe szczególne znaczenie chrześcijańskie przejawia w agapé, miłości bezinteresownej, pozbawionej choćby cienia erotyzmu. Taka właśnie miłość dowartościowuje, „taka jest zdolna do pochylenia się /... / nad każdą ludzką nędzą, nade wszystko zaś nad nędzą moralną, nad grzechem"30. A wtedy grzesznik doznający miłosierdzia nie poczuje się poniżony, co więcej, może nawet ożyć, jak ewangelista deklaruje słowami Ojca z przypowieści o synu marnotrawnym (por. $€ k 15,32$ ).

Bardzo interesująco komentuje zarysowany stan rzeczy P. Evdokimov: „Człowiek trwa w ciągłym zawieszeniu

\footnotetext{
28 Ktokolwiek by zabił Kaina siedmiokrotnej pomsty doświadczy, $R d z 4,15$. Zwróćmy uwagę, iż bezpośrednim kontekstem tych słów jest przekleństwo Boga i skazanie zbrodniarza na ciężką dolę ziemskiego przebywania (por. $R d z$ 4,10-12).

29 Por. Syr 17,1-7;

30 Św. Jan Paweł II, Dives in misericordia, IV,5.
}

między realizacją bytu, do którego został powołany, a powrotem do nicości, z której został wywiedziony; oto wielkie i wzniosłe ryzyko, a zarazem najwyższa nadzieja wszelkiej egzystencji”31, W rozumieniu teologii prawosławnej jest nawet tej egzystencji celem ${ }^{32}$, gdyż stanowi pełnię realizacji człowieczeństwa w kontekście podobieństwa Bożego ${ }^{33}$. Pozwala ono na funkcjonowanie bytu ludzkiego w szerokiej perspektywie istnienia Boga ${ }^{34}$.

Godność człowieka jest wielowymiarowa. Można ją uznać za naturalnie metafizyczną, gdyż człowiek ma udział $\mathrm{w}$ transcendentalnej dobroci jako przedmiot i podmiot miłości. Jest on niezależny, samoistny, zdolny do zwracania uwagi na siebie i koncentrowania się na sobie ${ }^{35}$.

Jako „korona wszelkiego stworzenia” dysponuje naturalną godnością fizyczną: obdarzony duszą nieśmiertelną, rozumem i wolną wolą może panować nad stworzeniami cielesnymi.

Dysponuje też godnością nadprzyrodzoną jako umiłowane Boże dziecko, osoba konsekrowana przez sakramenty, przybrany brat Bożego Syna, świątynia Ducha Święte$\mathrm{go}^{36}$. Jest zatem otwarty na Boże działanie i nawet $\mathrm{w}$ razie wyboru zła, odzyskuje możliwość nawrócenia.

A zatem godność ludzka osadzona jest zarówno na wielkości Boga, jak i wielkości powołania ludzkiego; na otwartości człowieka zarówno na sprawy wielkie, jak i bardzo małe. Ta wielowymiarowa i wielostopniowa otwartość przejawia się w szczególnym wymiarze życia duchowego, które Ortodoksja nazywa przebóstwieniem.

\section{b) Tajemnica przebóstwienia}

Fundamentem idei przebóstwienia jest prawda o Wcieleniu i Zmartwychwstaniu Chrystusa. Jak słusznie zauważa św. Ireneusz z Lyonu „Bóg stał się człowiekiem, aby człowiek stał się bogiem”. Ta szczególna zdolność domaga się jednakże Zmartwychwstania chrystusowego, czyli apogeum antropologicznego wymiaru obrazu i podobieństwa Bożego. Zmartwychwstanie bowiem to nie tylko zwieńczenie dzieła odkupienia, lecz również triumf ludzkiej natury przejętej inkarnatywnie przez Boga i uwielbionej przez Niego. W ten sposób zmartwychwstały Chrystus odsłania najistotniejszy cel stworzenia ${ }^{37}$.

Św. Maksym Wyznawca posługując się barwnym językiem, przebóstwienie nazywa udziałem „całego człowieka w całym Bogu", wskazując, iż udział ten dokonuje się w podobny sposób jak jednoczenie duszy z ciałem $\mathrm{w}$ procesie zaistnienia nowego człowieka. Innymi słowy możemy postawę Boga określić jako „inicjatywną”, otwierającą się w sposób dynamiczny i twórczy na ludzką egzystencję, by dać człowiekowi szansę udziału w egzystencji Jego. Takie oddziaływanie Boże zauważyć się da zwłaszcza w wymiarze cielesnym: ciału zapewniona zostanie nieśmiertelność,

\footnotetext{
P. Evdokimov, Poznanie Boga w Kościele Wschodnim: patrystyka, liturgika, ikonografia, przekład Alina Liduchowska, Kraków 1996, s. 29.

32 L. Uspienski, Teologia ikony, Poznań 1993, s. 191.

33 G. I. Mantzaridis, dz. cyt., s. 28 - 29.

34 W. Hryniewicz, Bóg naszej nadziei, t 1, Opole 1989, s. 129 - 130.

35 Summa teologiczna, artykuł 2.

36 Tamże

37 G. I. Mantzaridis, dz. cyt., s. $24-25$.
} 
dusza zachowuje swój niezmienny charakter. Wtedy przebóstwiony z łaski Bożej człowiek zyskuje zarówno na swej integralności, jak i na zdolnościach do pełnego odwzorowania Boga ${ }^{38}$, trwając w pełnym z Nim zjednoczeniu.

Odwołując się do Psalmisty, św. Jan powtarza: „Ja [Bóg] rzekłem: bogami jesteście" (J 10, 34). Człowieka zaś nazwano Bogiem nie na podstawie jego natury czy relacji, lecz z Boskiego rozporządzenia i łaski ${ }^{39}$. „Bóg w swej pełni przebóstwia tych, którzy są tego godni, jednocząc się z nim nie hipostatycznie - taką jedność osiągnął jedynie Jezus Chrystus - ani istotowo, lecz poprzez małą część niestworzonych energii i niestworzoną Boskość" - komentuje św. Grzegorz Palamas ${ }^{40}$.

Poprzez przebóstwienie człowiek realizuje swoje podobieństwo do Boga, stając się w ten sposób hipostazą bytu doświadczającego Boga w sposób szczególny ${ }^{41}$.

\section{Zakończenie}

W swoim wystąpieniu starałem się przedstawić zagadnienie rodziny w odniesieniu do inicjalnego, a zarazem bardzo istotnego jej paradygmatu. To właśnie w Raju pojawia się zagadnienie, które stanie się pryncypialnym nie tylko dla refleksji teologicznej, lecz, a może przede wszystkim socjologicznej, humanistycznej, antropologicznej czy filozoficznej.

Zagadnienie rodziny odsłania nam zawsze rzeczywistość świętą, przez Boga uświęconą, w ustach proroków (np. Ozeasza) reprezentujących jakość oddziaływania Bo-

\footnotetext{
38 Cyt. za tamże, s. 212.

39 W. Łosski, dz. cyt., s. 109-110.

40 Cyt. za J. Meyendorff, Teologia bizantyjska: historia i doktryna, przekład J. Prokopiuk, Warszawa 1984, s. 213.

41 W. Hryniewicz, dz. cyt., s. 143. Bardzo merytoryczne rozważania na temat rozróżnienia pomiędzy obrazem Boga w człowieku, a jego podobieństwem do Boga - patrz Bp Maximos (Aghiorgoussis) Wiara Kościoła [w:] Prawosławie - światło wiary i zdrój doświadczenia, pod red. K. Leśniewski, J. Leśniewska, Lublin 1999, str. 25-47.
}

żego na ludzi, na Cerkiew, na wierzących. Rodzina jest szansą rozwoju człowieka w całokształcie jego godności i potencjału religijnego. Miara człowieczeństwa, pleroma osiągnięta w rodzinie nie dla wszystkich dana jest jednakowo, zawsze jednak z indywidualną optymalizacją.

Paradygmat Edenu ukazuje nam, acz językiem poetyckim, dynamiczny wzorzec rodzinnego bytowania, prezentując z jednej strony jego teocentryzm, $\mathrm{z}$ drugiej zaś antropocentryzm. Obie rzeczywistości realizują się w harmonii i są względem siebie komplementarne.

Powtarzam raz jeszcze: w mym wystąpieniu nie chodziło o moralizowanie czy prezentację wyższości jednego systemu poglądów nad innym. Wystąienie to miało na celu raczej zainspirowanie pięknem przedstawionego tematu, pięknem co nieustannie wzrasta, jeśli się rodzi u samego Stwórcy.

Et si teologia sciit quomodo inspirare Juristas, missionem meam consummatam putabo.

[Jeżeli zaś teologia potrafiła zainspirować Prawników, uznam misję swoją za zrealizowaną].

\section{Summarium}

Paradigma Edeni et familia humana non in contrapositione, sed in integritate praesentantur. In lumine Edeni vita familiaris, consortio familiaris plenomodo illustrat dignitatem hominis et ejus capabilitates ad credendum. Auctor hujus articuli evitat tamen omnem formam proselitis$\mathrm{mi}$, in contrario, solum veritatem tam existentialem quam biblicam patristicamque solum presentare vult.

Paradigma Edeni, secundum Auctorem, tribus elementis consistitur: amicitia cum Deo, aequali dignitate humana (ipso gradu mulieris ac viri) et capacitate religiosa (theosis). In his tribus elementis aperitur atque dignitas familiae, principalis "cellulae" non solum societatis, sed praecipue Ecclesiae.

\section{Bibliografia}

Clement O., Ciało śmiertelne i chwalebne, Warszawa 1999.

Encyklopedia Chrześcijaństwa. Historia i współczesność. 2000 lat nadziei, wyd. JEDNOŚĆ, Kielce 2000.

Evdokimov P., Kobieta i zbawienie świata, przekład z francuskiego Elżbieta Wolicka, Poznań 1991.

Evdokimov P., Poznanie Boga w Kościele Wschodnim: patrystyka, liturgika, ikonografia, przekład Alina Liduchowska, Kraków 1996

Hryniewicz W., Bóg naszej nadziei, t 1, Opole 1989.

Kaszowski M., Żywy obraz i podobieństwo Boga, WWW.teologia (dostęp 10.XII.2014).
Łosski W., Teologia mistyczna Kościoła Wschodniego, przekł. Maria Sczaniecka, Warszawa 1989.

Łucarz S., Grób czy świątynia, Kraków 2007.

Mantzaridis G. I., Przebóstwienie człowieka, przekład Iga Czaczkowska, Lublin 1997.

Summa teologiczna, artykuł 2.

Św. Grzegorz z Nyssy, O naśladowaniu Boga, Kraków 2001.

Św. Jan Paweł II, Dives in misericordia, IV,5.

Uspienski L., Teologia ikony, Poznań 1993. 